\title{
Expand the Research and Practice of the Training Path of English for Military Cadets
}

\author{
Li Meng*, Song Mei, Hao Wenhui \\ College of Information and Communication, National University of Defense Technology Xi'an 710106, China \\ * Corresponding author: 405933257@qq.com
}

\begin{abstract}
English ability is an important branch of national defense language ability, but there is still an obvious gap between the English ability of Chinese military cadets and the training target of new military talents. There is no obvious difference between the English teaching of military academies and that of local academies. It is difficult to train English talents suitable for the army by using the same teaching materials and methods. It is of theoretical and practical significance to discuss the way of training the English ability of military cadets in order to improve the comprehensive English quality and ability of cadets, which will certainly promote the further construction of the new-type military personnel training system.
\end{abstract}

Keywords - national defense language ability; English training path; English language ability

\section{INTRODUCTION}

English ability is one of the basic abilities of college students, for the talent cultivation in the new era. The construction of foreign language competence of the armed forces is a major issue facing major countries ${ }^{1}$ in the world. The report to the 19th National Congress of the CPC states: "The world today is facing unprecedented changes and socialism with Chinese characteristics has entered a new era. In this crucial period of our new history, the responsibilities and missions of our armed forces have been expanding, from guarding our borders to participating in UN peacekeeping forces and international medical assistance; from disaster relief at home to fighting Somali piracy; from domestic military training to multinational joint military exercises and international military contests ; from focusing on military theories to participating in international military forums to make China's voice heard and China's position clear. This series of changes shows that China's military has stepped out of the country and strives to become a world-class military." A first-rate army needs not only first-rate weapons and first-rate military talent, but also first-rate language and communication skills, especially English. In February 2018, The China Military proposed for the first time that "national defense language ability" is another "important weapon" for winning future wars. In May 2018, the China Military Website stressed once again that "national defense language capability" is an "important standard" for building a world-class military. There is no doubt that English ability is an important branch of national defense language ability. In the Opinions on Deepening National Defense and Military Reform published by President Xi
Jinping in 2016, in the training of new military personnel. The Opinions call for the establishment of a new-type military personnel training system integrating military academy education, military training practice and military vocational education in accordance with the law of military personnel training. However, there is still a significant gap between the English ability of Chinese military cadets and the training goal of new military talents. For example, there is no significant difference in English teaching between military academies and local academies, using the same teaching materials and methods, it is difficult to train the English talents suitable for the army ${ }^{[1]}$. China's Ministry of National Defense lacks the standards for measuring the English proficiency of military personnel, and is unable to timely deploy the most suitable translators to the appropriate positions, the officers and soldiers who participate in joint military exercises often stumble in oral English, and the English language of cadres is inadequate for their work ${ }^{[2]}$. How to expand the training path of language ability of military cadets is an urgent problem to be solved in military academies in the new era. In the era of rapid development of information technology, the road to a strong military cannot be closed and self-confident, but requires extensive contact with the militaries of other countries. In the process of multi-communication, continuous learning and understanding the world, it is necessary to learn multiple thoughts. Multi-communication puts forward all-round requirements for the language ability of military cadets. It is of theoretical and practical significance to discuss the way of training the English ability of military cadets in order to improve the comprehensive English quality and ability of cadets, which will certainly promote the further construction of the new-type military personnel training system. 


\section{ANALYSIS OF RESEARCH STATUS AT HOME AND ABROAD}

The Standards for Foreign Language Learning in the 21st Century in the US has summarized the foreign language learning goals as 5C: Communication, Cultures ,

Connections, Comparisons, Communities. They are interdependent, mutually reinforcing, combined, permeated and supported. They cannot be separated. 5C learning goal is not only the core content of the "Standard", but also reflects the latest contemporary language acquisition theory and represents the 21 st century foreign language teaching reform and development direction in the United States.

In recent years, with the increasing number of our military missions involving foreign elements, new and higher requirements have been put forward for our personnel's English ability and foreign language teaching in military academies ${ }^{[3]}$. However, due to the long-term adoption of the general foreign language teaching mode in line with the local universities, the English teaching of military academies lacks the clear military application guidance in terms of teaching content, teaching methods and assessment standards. There is almost no research on how to cultivate the language ability of military students. It has become the consensus of English teaching staff in the military to promote the transformation of English teaching to military application. A systematic project of cultivation path cannot be realized simply by changing teaching contents and adjusting teaching objectives. From the perspective of practice, there are still some problems in foreign language teaching in military academies, such as the lack of military needs in the docking of teaching objectives, the support of teaching content, the unreality of training objectives, and the inaccuracy of the evaluation indexes in teaching effects ${ }^{[4]}$.

In terms of military foreign language ability building, Wen Qiufang's paper introduces the foreign language talent training system of West Point Military Academy in detail, which involves teaching staff, professional degree types, overall curriculum setting, professional course requirements, extracurricular activities, professional measurement indicators and graduates' whereabouts, summarizing its outstanding features and its enlightenment to the construction of foreign language courses in military and local universities. The enlightenment to military academies from the training system of foreign language professionals in West Point military Academy is as follows: first, foreign language teachers in military academies should be further optimized, they should take turns to experience life in the army, or take up temporary posts in the army and engage in activities related to foreign languages. Second, foreign language courses in military colleges and universities should be militarized. We should never copy the curriculum of foreign language courses in local colleges and universities, moreover, we cannot simply design courses according to the internal logic of foreign language subjects. Taking language proficiency as an example, different jobs require different levels of listening, speaking, reading, writing and translating skills. Therefore, in limited time, emphasis can be laid on the cultivation of the five skills

Although our army pays more and more attention to improving the English ability of military personnel at present, the evaluation of English ability of military personnel has not yet formed a foreign language ability standard that can meet the needs of the army and reflect the characteristics of the army. Instead, we refer to the common English ability standard of college English, CET-4, CET-6, PETS and other domestic standards. This kind of evaluation standard cannot directly reflect whether the soldiers participating in the test can meet the requirements of carrying out external tasks in terms of foreign language proficiency, let alone carry out targeted later training. For example, most of our peacekeeping officers in Lebanon are limited to daily communication, and more than $67 \%$ of them still have great difficulties in attending military meetings in English ${ }^{[1]}$; In a survey of 96 military science and technology personnel with a master's degree or above, 66.1 percent said their English ability was simply unable or difficult to meet job demands ${ }^{[5]}$.How to improve the English level of military personnel as soon as possible to meet the needs of the transformation of military functions has become a hot topic. At present, in terms of the construction of the Army's English ability, the above paper has made an in-depth discussion from different angles and levels. Some suggestions are put forward, which are of good reference value to the construction of the language ability of our army and even the world-class army.

\section{REFORM OBJECTIVES AND RESEARCH CONTENTS}

The purpose of this paper is to construct a model of the English language ability of military cadets under the goal of new compound military personnel training, and further study the specific training path on this basis. The culture path is mainly discussed from the following aspects : firstly, reform of teaching mode, including mixed teaching and situational teaching as well as the application of flipped topic in Military English teaching; secondly, reform the teaching content, reasonably set up the courses, carry out the first class and the second class according to the form of basic courses and elective courses, increase the oral communication and cultural course content; thirdly, the reform of teaching materials, the selection of military professional English teaching materials, with military audio-visual lecture notes.

Language ability consists of three parts : "abstract declarative knowledge system, skills of applying pragmatic knowledge and practical application of language (listening/speaking/reading/writing)." Declarative knowledge system consists of phonetic knowledge, grammar knowledge, discourse knowledge, pragmatic 
knowledge, communicative strategy knowledge and so on; declarative knowledge system consists of phonetic knowledge, grammar knowledge, discourse knowledge, pragmatic knowledge, communicative strategy knowledge and so on; the actual use of language refers to the ability to communicate in real situations. The English ability of military cadets and soldiers refers to the ability of a contemporary soldier to deal with military-related communication situations and professional research in English, The scope of services involved includes "conventional war, non-conventional war (such as counter-terrorism, peacekeeping, etc.), military science and technology, military diplomacy, military intelligence, etc $^{[3]} "$. On the basis of understanding this theory, the content of this paper mainly focuses on the research:

\subsection{English Language Proficiency Index of Military Cadets}

At present, college students' English ability is mainly cultivated in six aspects: listening, speaking, reading, writing and translating. The Chinese English Proficiency Rating Scale released in 2018 further divides English language proficiency into three stages and nine levels. The level of English language proficiency is divided into six aspects: language comprehension, language expression, pragmatic competence, language knowledge, translation competence and language use strategy。 Based on the research of college English language ability in China, in combination with the English Teaching Requirements for Undergraduates in Military Colleges and Universities formulated by the headquarters, further explore the requirements of military English teaching objectives on the English language proficiency of military cadets under the background of deepening national defense and reform, and on this basis, study the indicators of English language proficiency of military cadets.

\subsection{An Empirical Study on The English Language Ability of Military Cadets}

Through questionnaire survey and teacher-student interview, this paper investigates and analyzes the influence of the differences in English language ability of military cadets and their personal characteristics (school, training level, military experience, years of enlistment, grade, gender, etc.) on their English language ability.

\subsection{Applied Research on English Language Ability of Military Cadets}

It refers to the comprehensive course of Military English and the elective course of spoken Military English. Combined with the newly compiled textbook Military
English Comprehensive Course and the optional course handout Military English Audio-visual and Oral, In the process of military English teaching, students not only pay attention to the learning and mastery of phonetics, grammar, vocabulary and other basic language knowledge, but also focus on the cultivation of military professional English ability.

\begin{tabular}{|c|c|c|}
\hline \multicolumn{3}{|c|}{ Focus Study } \\
\hline 1. English & 2. An Empirical & 3. Applied \\
Language & Study on The & Research on \\
Proficiency & English & English \\
Index of Military & Language & Language \\
Cadets & Ability of Military & Ability of Military \\
& Cadets & Cadets \\
\hline
\end{tabular}

\section{CONCLUSION}

In a word, this study will carry out in accordance with the general idea and then the key points, specifically divided into three main stages: theoretical analysis, teaching plan design and teaching reform summary. Among them, the main work in the theoretical analysis stage is to investigate and sort out the current situation of the English language ability of military cadets, make clear how to carry out existing practical teaching under the guidance of theory, and determine in detail how to logically divide the main content of the research. The main work in the stage of teaching plan design is to design the teaching materials, teaching modes and teaching means according to the specific teaching objects of military cadets, focus on training the cadets' ability to use the language form structure system itself, and implement targeted English teaching of military cadets according to the design scheme. After completing the implementation of the teaching method, summing up, and then identifying and solving problems can lay a solid theoretical foundation for further establishing mature theory.

\section{ACKNOWLEDGMENT}

College of Information and Communication, National University of Defense Technology in 2019, results of project "Construction and Application of Foreign Language Proficiency Indicators of Military Cadets". 


\section{REFERENCES}

[1] Li Hongqian. The Status Quo and its Means of Foreign Language Skills of Chinese Military Peacekeepers- Take UNIFIL For Example [ J ] . Journal of Higher Education , 2009 , (2) : 38-40

[2] Fu Yansong, Peng Tianyang. The Thinking and Countermeasures of the Building of National Defense Language in the New Situation [ J ] . Journal of Yunnan Normal University (the Philosophical Social Science Edition), 2014, (3): $18-22$.

[3] Wen Qiufang. The Ability of the Military Foreign Language and its Formation-Inspiration from the National Defense Language Change Roadmap [ J ] . Foreign Language Research , 2011 ，(4) : 1-7

[4] Ma Xiaolei, Hu Xiaotang. Thinking and Suggestion of Foreign Language Teaching Planning in Military Academies [ $\mathrm{J}$ ] . Journal of Foreign Languages Institute of the PLA , 2018，6th, Volume 6.

[5] Li Hui, Liu Fang. The Improvement of Foreign Language Application Ability of Military Technology Personnel in the New Era [ J ] . Journal of Higher

Education , 2009, (3) : 39-41 